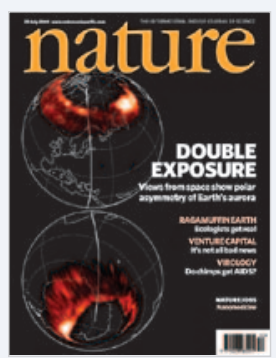

Vol. 460 No. 7254 23 July 2009
2 つの観測衛星によるオーロラ撮影 : 宇宙からの観察で明らかに なった地球両極の才一ロラの非対称性

DOUBLE EXPOSURE: Views from space show polar asymmetry of Earth's aurora

北半球で見られる北極光と南半球で見られる南極光は、互い に鏡像関係にあると広く考えられている。しかし、常にそうだ とは限らないことを示す新たな証拠が得られた。オーロラは、 北極圈と南極圏の地磁気の磁力線によって結びつけられた場 所で同時に発生しやすい。そして、この関係が、北極と南極 のオーロラのパターン、位置、出現のタイミングを結びつけ ているのだろうと考えられている。2001 年5 月12 日には、 IMAGE と Polar の 2 つの地球観測衛星が、南極と北極の両 方を同時に観測するのにちょうどよい位置にあった。こうして 得られた画像が今回解析され、オーロラが非対称でありうるこ とを示す明らかな証拠がもたらされた。非対称性は、両半球 間に流れる電流（伝導率の違いによって生じると予測されてい るが、これまで実証されたことはない）によるものである可能 性がある。表紙は、同時に撮影された南北両半球の画像で、 上が IMAGE-WIC の撮影した北半球、下が Polar VIS Earth Camera の撮影した南半球である。

Letter p.491 参照
免疫 : チンパンジーも「エイズ」にかかる 'AIDS' in chimpanzees アフリカの霊長類に感染するサル免疫不全ウ イルス (SIV) には 40 種以上が存在し、そ のうち 2 つが種の壁を乗り越えて、ヒトでエ イズウイルス HIV-1 とHIV-2が生じた。今回、 タンザニアのゴンベ国立公園で野生状態で 生活しているチンパンジーについての包括 的な自然史研究によって、HIV-1 の前駆ウイ ルスであるSIVcpz に関する一般的な説、つ まりすべてのSIV は自然宿主には病原性を 示さないという広く受け入れられてきた考え が覆されることになった。9 年以上にわたっ て 94 匹のチンパンジーを追跡調査した今回 の研究によって、SIVcpz 感染により、10 倍 以上の死亡リスク、出生率低下や進行性の $\mathrm{CD} 4^{+} \mathrm{T}$ 細胞数減少といったエイズに似た徴 候がチンパンジーでもみられることが明らか になったのである。これらの近縁のレトロウ イルスが病気を引き起こす機序をヒトとチン パンジーとで比較すれば、HIV 感染の予防 や治療のための薬剤やワクチンの開発に関 係のあるウイルス因子や宿主因子の同定が 可能になるかもしれない。

Letter p.515, N\&V p.470 参照

環境 : 湖沼の生産力を制限するのは光 Light limits lake productivity

湖沼生態系の生産力は、利用可能な栄養素 の量によっておおむね制限されると一般に考 えられている。しかし、スウェーデン北部の 12 の天然湖沼に関する研究で新たな知見が
得られ、その考え方に異議が出された。そ の湖沼群では、バイオマスの蓄積に対する 制限要因が栄養素の供給量ではなく、光の 供給量であることが明らかになったのであ る。天然湖沼の多くはこの湖沼群と同様に 比較的小規模で栄養素の量が少ないことか ら、大多数の湖沼は光による制限を受けて おり、栄養素に生産力が左右されるのは、 主として栄養素の流入量が特別に多い湖沼 だろうと考えられる。

Letter p.506, N\&V p.463 参照

量子情報科学: 量子論で確かめられたコンテ クスチュアリティ

\section{Quantum theory in context}

量子力学は、初めて導入されて以来これま で、ほぼ 90 年間にわたって大きな成功をお さめ、その予測は多数の実験で確かめられ ている。にもかかわらず、この理論の公理 に満足していない物理学者の多くは、量子 物理学の予測を古典論で説明しようと試みて いる。古典モデルの直感的な特徴は、ノン コンテクスチュアリティ、つまりどのような測 定も、同時に行われ、両立可能なほかの測 定の結果とは独立な值をもつという性質であ る。理論から、ノンコンテクスチュアリティは 量子力学と矛盾することが示唆され、光子と 中性子で行われた実験もこれを支持している ようだ。しかし、これらの検証には特殊な量 子状態を発生させることが必要であり、いく つかの抜け穴が残っている。今回 Kirchmair たちは、トラップイオンを使って、こうした問
題を克服し、ノンコンテクスチュアルな観点 では説明できない実験を行った。したがって、 コンテクスチュアリティは、特殊な量子状態 や量子もつれを発生させる必要のない自然 界の性質であるということになる。

Letter p.494, N\&V p.464 参照

\section{細胞：p53 と miRNA のつながり}

\section{Link between $p 53$ and miRNA}

がん抑制因子 p 53 は、増殖抑制作用をもつ 多くの標的に転写アクチベーターとして作用 することがよく知られており、p53 の機能崩 壊は大半のがんの発生時にみられる基本的 現象である。マイクロRNA（miRNA）はが んの抑制にかかわる重要な因子であることが わかってきているが、今回、p53 と miRNA の間に意外な結びつきがあることが明らかに なった。転写調節という役割とは全く別の相 互作用において、p53は miR-16-1、miR143、miR-145 などの増殖抑制作用をもつ miRNA の転写後成熟を DNA 損傷に応じて 促進する。このことは、miRNA の生合成を 調節する p53 の働きが、そのがん抑制機能 に寄与している可能性を示唆している。

Letter p.529, N\&V p.466 参照

\section{地球 : 景観の説明}

\section{Landscape explained}

多くの丘陵地帯の景観では、上空から見ると 尾根と谷が一様な間隔で並んでいるように見 える。景観進化に対する現在の物理モデルで は、現実のもののように見える地形が得られ るが、自然景観にみられる等間隔で並んだ 尾根と谷に典型的な「波長」は予測できない。 Perronたちは、質量保存と堆積物輸送の方 程式を用いて、地形進化モデル、およびカリ フォルニア州のナパバレーやユタ州のポイン トオブザマウンテンなど、米国内 5 か所の野 外調査で得られた尾根と谷の波長と正比例す る特徵的な長さスケールを導き出した。この 知見によって、景観の最も広くみられる特徵 の 1 つが定量的に説明され、谷の間隔は、 物質の性質と気候が浸食過程に及ぼす影響 を記録していることが示唆される。

Letter p.502, N\&V p.468 Making the paper p.434 参照

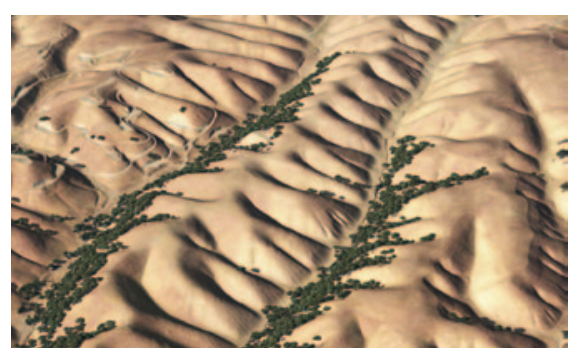




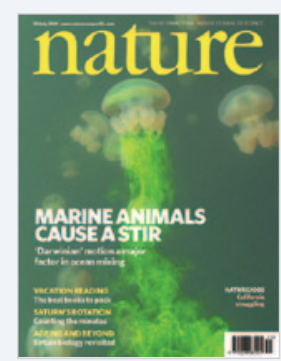

Vol. 460 No. 7255

30 July 2009
海洋動物が引き起こす混合 : ダーウインが考えた生物起源の流体 混合は海洋混合における主要因子だった

MARINE ANIMALS CAUSE A STIR: 'Darwinian' motion a major factor in ocean mixing

高名なチャールズ・ダーウィンの孫である物理学者のサー・ チャールズ・ダーウィンのほとんど忘れられていた成果が、海 洋混合についての長年の論争を解決することになった。1953 年に彼は、遊泳動物が海洋における水の混合に大きく寄与す ることになる機構を提案した。海洋で生物が引き起こす混合 についての論争は現在のところ、動物運動の後流が起こす乱 流と海洋乱流の比較に注目が集まっている。「ダーウィン」混 合はこれとは異なり、流体の中を移動する固体が周辺の液体 の一部を動かし、その動きが固体とともに伝搬していくとき に生ずる。K Katija とJ Dabiri は、離島の湖で遊泳中のクラ ゲについての野外測定結果を新しい理論モデルと結びつけ、 ダーウィン混合という機構を介しての生物の海洋混合への寄 与が、風や潮汐と同程度という、相当な規模になることを示 している。表紙は、パラオの「クラゲ湖」でMastigias sp. のクラゲが起こす誘起流体ドリフトを、色素により測定してい る際のものである。

Letter p.624, N\&V p.581 参照

見は、気候温暖化が、従来の想定を大きく 超える規模で泥炭地帯の地中に蓄積された 炭素の呼吸を加速しており、京都議定書で EU 全体が目標とする温室効果ガス排出量削 減分のほとんどが、これにより相殺される可 能性があることを示唆している。

Letter p.616 参照

神経 : プレセニリンは神経伝達物質放出を制 御している

Presenilins action

プレセニリン遺伝子は、家族性アルツハイ マー病と遺伝的に関連があるが、この遺伝 子がニューロンのどこで、どのように働いて いるのかはよくわかっていなかった。Zhang たちはマウスモデルを使い、プレセニリンは シナプス前部で働き、ニューロンの計算、学 習、記憶に必須の過程である活動依存性神 経伝達物質放出を制御していることを明らか にしている。この結果から、シナプス前機能 不全が神経変性疾患における認知症の早期 段階の原因である可能性が考えられる。

Letter p.632, Abstractions p.550 参照

生化学 : P2X 4 と ASIC1 の構造は似ている $\mathrm{P}_{2} \mathrm{X}_{4}$ and $\mathrm{ASIC1}$ at the gate P 2X 受容体はATP 依存性の非選択的陽イ オンチャネルで、痛覚や炎症反応に関連し ているが、その構造はまだわかっていない。 Kawate らは今回、閉状態のゼブラフィッシュ P $2 X_{4}$ 受容体の結晶構造を報告している。 その三量体構造から、リガンド結合、陽イオ ンの進入やチャネル開閉の分子基盤のいく つかが明らかになった。同じグループのもう 1 つの論文では、ニワトリの脱感作状態に ある酸感受性イオンチャネル 1 (ASIC 1) の 構造が示されている。P2X受容体と同じよ うに、ASIC も三量体だが、これら 2 つは全 く異なるイオンチャネルファミリーに属する。 ASIC1 の構造決定により、イオン透過と脱 感作が起こる仕組みと思われるものが示さ れた。また、ASIC とP $2 X$ の構造の比較か らは、これらの機能的に異なるチャネルが同 じような機構的な原理を採っていることが示 唆される。

Articles pp.592, 599, N\&V p.580 参照

宇宙 : 新たに得られた土星の自転周期

Saturn's rotation

土星の全体としての自転周期は、過去数十 年間にわたり、目立った変化をしてきたと は考えられていない。そうすると、自転周 期の代理となるような尺度も、ほとんどー 定の值だったとしてよいはずだ。カッシーニ 計画で得られた最近の成果は、従来土星内
部の自転周期を決定しようと行われてきた、 磁気圏の特徵の自転周期の測定という方法 に疑問を投げかけている。なぜなら、この ような方法では、ボイジャーが 28 年前に測 定した 10 時間 39 分 24 秒より約 7 分長い 周期が得られるからだ。Readたちは新た に、大気のポテンシャル渦度の分析に基づ いて、土星の自転周期を 10 時間 34 分 13 秒 \pm 20 秒と決定した。この基準座標系の 変更は、互い違いに現れるジェットのパター ンと一致するもので、土星の風はこれまで 考えられてきた以上に、木星のものに似て いることが示唆される。

Letter p.608, N\&V p.582 Making the paper p.550 参照

環境 : 泥炭から放出される炭素

Carbon released from peat

数百年から数千年前に形成された泥炭堆積 物の呼吸活性化を介する $\mathrm{CO}_{2}$ 放出の気候 温暖化による加速は、地球の気候に対する 強い正のフィードバックとなる可能性がある。 しかし、泥炭地帯、特にその深部に存在す る炭素の長期的な温度感受性は、まだはっ きりわかっていない。今回、亜北極域の泥 炭地帯で行われた長期（8 年以上）の人工 温暖化実験により、約 $1^{\circ} \mathrm{C}$ の温暖化が生態 系の呼吸を $50 \%$ 以上加速し、その加速の 大部分が、永久凍土上の活性層の底部付近 に存在する、取り扱いが困難な古い炭素に 由来していることが明らかになった。この知
工学 : 粉粒体パッキングのモデル化

Going with the grain

粉粒体がランダムに集合する性質は、物理 学や数学の分野における遠い昔からの基本 的問題であり、多孔質岩石を通した石油の 抽出、穀物の貯蔵、粉末からの錠剂製造 など、さまざまな場面で実際に適用されて いる。これまで、粉粒体に関して、結晶秩 序化に類似する単純な基本的機構は知られ ていなかった。ニューヨーク大学のチーム は、多分散エマルション滴のパッキングを測 定し、全体的なパッキング構造の複雑さは、 「granocentric（粒子中心的）」な観点から 理解できることを見いだした。粒子周囲の 利用可能空間と隣接粒子との接触率という、 2 つの単純な局所パラメーターに基づく統計 モデルによって、連接性や密度を含めてパッ キングの局所的および全体的特性の両方が うまく予測される。

Letter p. 611 参照

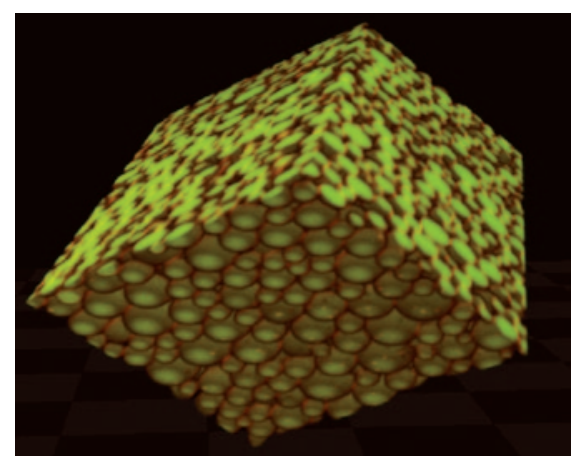




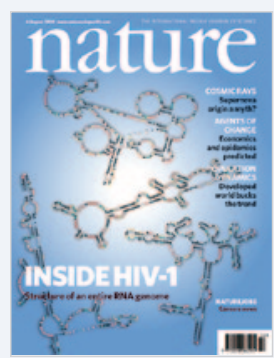

Vol. 460 No. 7256 6 August 2009

HIV-1 の内部事情 : 全 RNA ゲノムの構造 INSIDE HIV-1: Structure of an entire RNA genome

完全な HIV-1 ゲノム RNAの二次構造が決定された。これ は、感染性ウイルス粒子から抽出された真正の HIV RNA の 解析に基づくものである。ウイルスの一本鎖 RNA ゲノムの二 次構造が機能的また調節的役割を果たすことは知られている が、今までのところ、どんなウイルスについても全 RNA の包 括的な解析は行われていなかった。今回、HIV-1 ゲノム RNA が形成する全体構造の特徵を調べるのに、SHAPE（highthroughput selective $2^{\prime}$-hydroxyl acylation analysed by primer extension）という技術が使われた。高度に構造化さ れたモチーフが多数見いだされ、また、これらの多くについ て機能の推定が行われている。RNA の構造要素の存在が、夕 ンパク質の翻訳に影響し、またタンパク質の適切な折りたた みを促進していることがわかったのは重要である。これらの結 果は、HIV-1 ゲノムが確かに構造をもち、その構造成分がウ イルスの適応に非常に重要であることを強調している。この研 究から得られる考察は、HIV-1 の生物学的性質の解明を進め、 新しい抗レトロウイルス療法につながるだろう。

Article p.711, N\&V p.696 参照

環境 : 先カンブリア時代の緑化

Greening the Precambrian

過去 10 年間に行われた数十件の研究で、 新原生代の炭酸塩岩における炭素同位体の 変動が報告されており、地球の炭素循環の 変動と関連付けられている。P Knauth と M Kennedy は、炭素同位体分析の一部として 必ず得られるものだが、見過ごされることの 多かった酸素同位体測定值（標本数は 2 万 点を超える) に注目するという独特の視点か ら、それらのデータを検討した。そして、酸 素同位体組成と炭素同位体組成の組み合わ せが、よく研究されている顕生代の標本と一 致するという予想外の結論が得られた。この 顕生代の標本は、陸上のファイトマス（植物 系バイオマス）に由来する、光合成で作ら れた炭素が地下水に運ばれて大規模に流入 した沿岸の間隙水中で石化したものである。 新原生代の炭酸塩における ${ }^{13} \mathrm{C} /{ }^{12} \mathrm{C}$ の広く 報告されている低下は、炭素循環の変動で はなく、顕生代標本との類似性によって解釈 するほうが無理がない。またそれは、先力 ンブリア時代末期の、光合成を行う藻類や コケ類、菌類からなる敷物で覆われた地球の 「緑化」を示唆している可能性がある。酸 素とファイトマスを生み出すこのような事象 は、先カンブリア時代のほとんど微生物だけ だった世界から、カンブリア紀の後生動物の 世界への決定的な移行の間接的原因となっ た可能性さえある。

Letter p.728, N\&V p.698 Making the paper p.666 参照
考古 : 初期の音楽活動

Early music movement

今週号に掲載されている、ドイツ南西部の ホーレフェルス洞窟で発見された鳥骨製の 5 穴の笛についての論文によれば、ヨーロッ パに最も早くに住み着いた現生人類は、既 に高度な音楽的伝統をもっていたらしい。こ の笛は、約 3 万 5000 年前のものである。 年代が同じくらいの笛はほかにも知られてい るが、これほど洗練されて完成度の高いも のはない。この笛は、同じ研究グループが 最近発見したマンモスの牙で作られた女性 小立像のすぐそばで見つかった。

Letter p.737, N\&V p.695, Abstractions p.666 参照

\section{人口統計学 : 世界人口の動向}

\section{Global population trends}

国が豊かになるとそれに伴って出生率が低 下するため、多くの先進国（と一部の発展 途上国）では出生率が、人口置換水準 (1 人の女性が一生の間に産む子どもの数が約 2.1 人) 以下に低下している。この「少子化」 と人口高齢化が合わさって、多くの難しい 社会問題や政治問題が生じている。しかし、 Myrskyläたちは今回新たに、合計特殊出生 率と人間開発指数との関係を横断的および 縦断的に分析し、経済がある程度以上に発 展すると、出生率が再び上昇し始め、人口 高齢化の速度が遅くなることを明らかにして いる。その結果、現在の一般的議論や科学 者による議論とは対照的に、最も発展した 段階に達した国は、人口が比較的安定する
と考えられ、ある程度の移民がある場合に は、総人口が増える可能性が高い。

Letter p.741, N\&V p.693 参照

\section{医学 : 統合失調症のリスク因子}

\section{Schizophrenia risk factors}

今週号では、3つの論文が遺伝子変異と統 合失調症のリスクについて考察している。 国際統合失調症コンソーシアムは、主要組 織適合遺伝子複合体 (MHC) 遺伝子座内 に一般的な変異群を同定し、影響が非常 に小さい数千の共通対立遺伝子を含む、ポ リジーン構成要素が統合失調症のリスクに 相当度関与していることの分子遺伝学的 証拠を示している。これらの対立遺伝子群 は、双極性障害のリスクにも関与している。 H Stefanssonたちは、一塩基多型に関す る全ゲノム関連解析を行い、免疫、脳の発 達、記憶および認知に関係するとされる個々 の遺伝子座と統合失調症への素因の間に、 有意な相関がみられることを報告している。 J Shiたちは、症例対照研究を設計し、ゲノ ムの MHC ゲノムの遺伝子座と統合失調症 の関連を明らかにしている。彼らの結果は、 この疾患にクロマチンタンパク質がかかわ っている可能性を示唆している。まとめると、 約 1 万例の患者と約 2 万の対照とによるメ 夕解析は、一般的な複数の遺伝子変異が統 合失調症のリスクに影響を及ぼしているが、 大きな影響を及ぼす単一の一般的遺伝子座 はごくわずかか、あるいは全くないことを示 している。

Letters pp.744, 748, 753 参照

\section{宇宙 : 火星でのメタン生成の謎}

\section{Methane making on Mars}

火星上のメタンの最近の観測結果は、メタン 濃度が局所的に高くなり、季節とともに変化 していることを示唆している。しかし、メ夕 ンは、光化学反応における寿命が数百年と いう長さであるため、火星全体で均一に分 布していると考えられている。F Lefèvre と F Forget は、化学反応を組み込んだ火星の 全球気候モデルを使い、火星のメタンに最 近観測された変化が、メタンの光化学反応 についての我々の考えにどうかかわってくる かを調べた。現在考えられているような光化 学反応では、メタン濃度に測定可能な変化 が現れず、報告された観測デー夕を説明す るためには火星表面のメタンの分解が極端 に速くなければならないだろうことが示され た。火星のメタンに何が起こっているのかを 正確につかむためには、in situ 観測を行う 将来の火星探査機を待たなければならない だろう。 Letter p.720 参照 


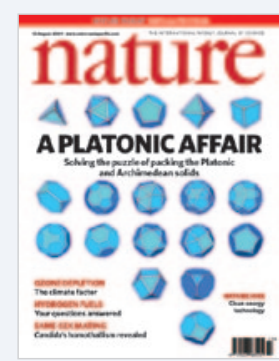

Vol. 460 No. 7257

13 August 2009
プラトン立体を詰め込む : プラトン立体とアルキメデス立体の充填 の問題を解く

A PLATONIC AFFAIR: Solving the puzzle of packing the Platonic and Archimedean solids

粒子の高密度充填の幾何学的知見に基づくモデルは、液体、 ガラス、結晶、粉粒体、生細胞など、多くの系の構造を説明 するのに役立つ。この分野における以前の研究のほとんどは、 球状粒子に注目しているが、このような理想的な形状の場合で すら、問題は非常に難しく、球の最密充填に関するケプラー予 想が証明されたのは、2005 年になってからである。18 の古 典的幾何形状、すなわちプラトン立体やアルキメデス立体（表 紙に示されている）は古代ギリシャ時代から知られている形だ か、それらの最密充填配置については、ほとんどわかっていな い。今回、S Torquato とY Jiao は、5つのプラトン立体（四 面体、立方体、八面体、十二面体、二十面体）と 13 のアル キメデス多面体の既知の最密充填体について報告している。 これらの立体の対称性は、基本的な充填配置を決定するうえ で極めて重要であり、中心対称性をもつプラトン立体とアルキ メデス立体の最密充填は、対応する最密（ブラヴェ）格子充 填で与えられると予想される。 Letter p.876, N\&V p.801 参照

\section{進化 : 初期の体内受精}

Early internal fertilization

板皮類は、原始的な甲旮魚類に属する大規 模な一群である。完全に絶滅してしまってい るが、その不思議な体の構造は、人類を含 む有顎脊椎動物 (顎口類) の進化を解明す る手がかりとなる。今回、新たな化石の発 見で、Incisoscutum の生殖の仕組みが明ら かにされた。この化石魚類は、板皮類の中 でも重要で大きな分類群の 1 つである節頸 類の一種として注目されている。最近、保 存状態の良好なIncisoscutum ritchiei の雌成 体の化石が胎仔を伴って発見され、体内受 精が行われていたことが示された。今回の 新たな化石は同じ種の雄のものであり、腹 部に化石魚類のプチクトドゥス類（甲旮をも たない板皮類）やサメ類でみられるような陰 茎様の鯺脚があったことを示している。

Letter p.888, Abstractions p.780 参照

\section{細胞 : 酵母の同性接合}

Same-sex mating in yeasts

酵母の仲間で、カンジダ症や重篤な全身 性疾患の原因となるカンジダ菌 Candida albicans は、かつては無性生殖だけを行う と考えられていたが、通常はみられない 接合生活環も存在することが現在では知 られている。接合は一般に、近緑の酵母 Saccharomyces cerevisiae と同じ方式で、a 細胞と $\alpha$ 細胞との融合が起こる。今回、カ ンジダ菌の新しい有性生殖様式がもう 1 つ 見つかった。分泌型プロテアーゼをコード
する遺伝子 bar1 がないという特殊な条件下 では、 $\mathrm{a}$ 細胞どうしの間で同性接合が効率 よく起こる。カンジダ菌の同性接合と、カン ジダとは無関係な病原性真菌 Cryptococcus neoformans の同性接合との間に類似性があ ることから、この種の「ホモ夕リズム（同体 性)」が、哺乳類宿主内でのこれら真菌の生 存を助長している可能性が考えられる。

Letter p.890, N\&V p.807 参照

がん：がん遺伝子の機能獲得型变異

Gain-of-function oncogenes

正常なヒ卜細胞は、両親それぞれに由来す る完全な染色体セットをもっているが、が んの中には、特定の染色体の一部分が 2 つとも片方の親由来というものがあり、こ の現象は後天性の片親性二倍体とよばれて いる。骨䯣腫瘍患者から採取した 200 例 を超える骨髄試料のゲノム DNA 解析から、 第 11 染色体の一部の 2 つのコピーの両方 が片方の親由来という例が高率でみられる ことがわかった。こうした例では、腫瘍抑 制因子 C-CBL の機能獲得変異が生じており、 これが繊維芽細胞をがん化し、サイトカイ ン刺激に対して造血細胞の感受性を増加さ せる。今回のデータは、c-Cbl は増殖抑制 型の腫瘍抑制遺伝子でありながら、変異が 起こると、増殖を促進するがん遺伝子とな るという考え方を裏付けており、これは腫 瘍抑制遺伝子 p53 で明らかにされているの と同じ状況である。

Letter p.904, N\&V p.804 参照
細胞 : テロメアを守る

Protecting the telomere

真核生物の直線状の染色体の末端には、テ ロメアとよばれる配列がキャップのようにつ いている。テロメアは、DNA 二本鎖が切断 されて生じた一本鎖部分と、基本的には同 じ構造である。一般に二本鎖切断箇所は病 原となる損傷なので、ゲノムの完全性維持 のために修復されなくてはならないのだが、 テロメアは通常、DNA 損傷修復経路を活性 化しない。テロメア維持の過程で主に働くの は、MRE11、RAD50、およびNBS1 とい う3つのタンパク質からなる MRN 複合体で ある。今回、マウスで全 MRN 複合体ある いはMRE11 のヌクレアーゼ活性だけを不 活性化する対立遺伝子を用いた研究が行わ れ、MRE11 がテロメアで $2 つ$ つ機能を果 たしていることがわかった。MRE11 は、突 出 (オーバーハング) 部分の DNA 端の形 成促進により新たに合成されたテロメア端 を修復因子から保護し、またテロメアが適 切に機能しないときには、このような突出部 分を分解して融合修復を促進するのである。

Letter p.914 参照

\section{細胞 : 幹細胞の開放型クロマチン}

Open chromatin in stem cells

扁形動物から哺乳類まで、多くの幹細胞の クロマチンには凝縮した領域、つまりへテ ロクロマチンがほとんどなく、そのため転写 調節因子が近づきやすい開放状態になって いる。今回、マウス胚細胞で RNA 干渉によ る新規調節因子のスクリーニングが行われ、 クロマチンリモデリング因子 Chd 1 が胚細 胞の開放型クロマチンや多能性の維持、お よび体細胞の多能性状態への再プログラム 化に不可欠であることが示された。これは、 開放型クロマチンと多能性との間の因果関 係を直接示す証拠である。Chd 1 は生殖系 列幹細胞と成体幹細胞の両方で高度に発現 していることから、幹細胞にみられる開放型 クロマチンと分化能の関連性が一般的な現 象である可能性が出てきた。

Article p.863, N\&V p.802 参照

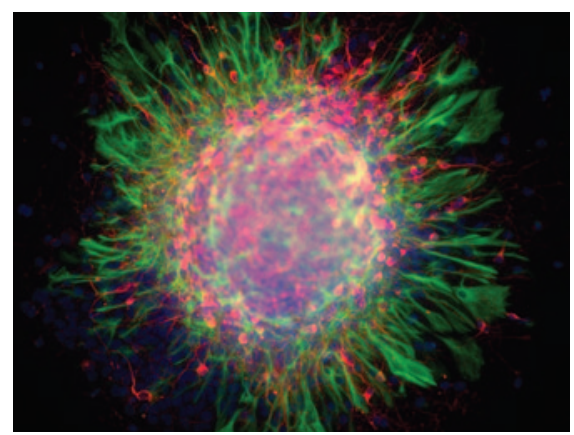

